\title{
Türkiye Taşınmaz Değerleme Sisteminin Etkinliğinin Araştırılması
}

\author{
Nuri ERDEM ${ }^{1 *}$ \\ ${ }^{1}$ Osmaniye Korkut Ata Üniversitesi, Mühendislik Fakültesi, Harita Mühendisliği Bölümü, Osmaniye \\ (nurierdem@osmaniye.edu.tr) ORCID ID 0000-0002-1850-4616
}

\begin{abstract}
$\ddot{O} \mathbf{z}$
Vergilendirme, kamulaştırma, özelleştirme, tescile esas işlemler, irtifak hakkı tesisi gibi kamusal uygulamalar ile sermaye piyasası, bankacılık, kredilendirme, sigortacılık gibi özel sektör uygulamalarında taşınmaz değerlerine ihtiyaç duyulmaktadır. Bu nedenle, ülkelerin gerek taşınmaz pazarlarının şeffaflığını sağlama gerekse kamu ve özel sektör uygulamalarının adaletli bir şekilde gerçekleştirilmesini temin etme amacıyla değerleme altyapılarını oluşturmaları büyük önem arz etmektedir. Ülkemizin taşınmaz değerleme sistemi incelendiğinde, bu alanda sağlıklı bir mevzuatın ve kurumsal yapılanmanın bulunmadığı, değerlemede ihtiyaç duyulan veritabanlarının ve değerleme modellerinin oluşturulamadığı görülmektedir. Bu çalışmada, ülkemizde taşınmaz değerleme alanında yürütülen faaliyetlere ilişkin mevcut durum tespiti ile bu alanda yaşanan sorunların ortaya koyulması ve çözüm önerilerinin geliştirilmesi hedeflenmiştir.
\end{abstract}

Anahtar Kelimeler: Taşınmaz dĕgerleme, Türkiye taşınmaz dĕgerleme sistemi,

\section{Investigation of the Effectiveness of Turkey Real Estate Valuation System}

\begin{abstract}
Real estate appraisal is required for both public applications (such as taxation, expropriation, privatization, real estate transaction and registry of an easement) and private sector applications (such as capital market, banking, credit facility and insurance). Therefore, it is very important for countries to build up an appropriate infrastructure for real estate appraisal in order to ensure the transparency of real estate markets and realize public/private sector applications equitably. If real estate appraisal system of Turkey is examined, the country does not have healthy regulations, an appropriate organizational structure, databases and models of real estate appraisal. In this study, it was aimed to determine the current situation related to the activities carried out in the field of immovable valuation in our country, to propose the problems experienced in this area and to develop solutions proposals.
\end{abstract}

Keywords: Real estate appraisal, Real estate valuation system in Turkey

\section{GIRIŞ}

Dünya değerler sisteminin bir aracı olan taşınmaz, sadece ülkemiz için değil tüm dünya halkları için, ekonomik ve sosyal açıdan önemli bir kavramdır. Dünya nüfusunun giderek artması, tarımsal faaliyet alanlarının azalması, köyden kente göç ve bunlara bağlı olarak meydana gelen hızlı kentleşme gibi etkenler, taşınmazların değerini gün geçtikçe daha da arttırmaktadır.

Günümüzde taşınmaz sektörü ve buna bağl1 olarak gelişen taşınmaz değerlerinin belirlenmesi hizmetleri, uluslararas1 küresel ekonomik ilişkilerin vazgeçilmez bir unsuru olmuştur. Değerleme faaliyetleri, ekonomik

\footnotetext{
* Sorumlu Yazar
} 
sistemde bir bütünün içinde geniş bir yer tutmakta ve farklı amaçlarla kullanılmaktadır. Taşınmaz değerlerinin belirlenmesi işi ve bu değerlerin likidite olarak piyasada işlem görebiliyor olması, sağl1klı bir ekonomik yapının en önemli unsurlarıdır (HKMO, 2012).

Uluslararas1 Haritacilar Federasyonu (FIG), Birleşmiş Milletler (BM), Avrupa Birliği (AB) ve Dünya Bankası (DB) gibi uluslararası organizasyonlar tarafından yayınlanmış olan temel bildiri, rapor ve deklarasyonlarda öne çıkan öngörüler içerisinde, kamu otoritelerinin taşınmaz pazar değerlerinin belirlendiği sistemleri oluşturması ve böylece taşınmaz pazarlarının şeffaflığının sağlaması gerektiği ifade edilmektedir (Çete, 2008; EU, 2004; Çete ve Yomralığlu, 2009). Değerleme alanında her ülkenin kendine özgü model ve standartları bulunmaktadır. Son yüzyılda yaşanan taşınmaz değerlerine bağlı küresel ekonomik krizler, uluslararası düzeyde değerleme standartlarının geliştirilmesi ve bilimsel temelleri güçlü değerleme sistemlerinin oluşturulmasını zorunlu kılmıştır.

\section{YÖNTEM}

$\mathrm{Bu}$ çalışmada, ülkemizde taşınmaz değerleme alanında yürütülen faaliyetlere ilişkin mevcut durum tespiti ile bu alanda yaşanan sorunların ortaya koyulması ve çözüm önerilerinin geliştirilmesi hedeflenmektedir. Bunun için öncelikle ülkemizin taşınmaz değerleme sistemiyle ilgili mevzuat, kurumsal ve teknik yapısının mevcut durumu araştırması yapılmış, sonrasında sistemin etkinlik araştırmasına geçilmiştir. Bu bağlamda, ilk olarak, araştırma yöntemi alternatifleri değerlendirilmiştir. $\mathrm{Bu}$ alternatiflerden biri, taşınmaz değerlemesi etkinlik göstergelerinin sorgulandığ 1 bir anket formunun oluşturulması, ilgili kurumlara gönderilmesi ve verilecek cevapların değerlendirilmesidir. İkinci alternatif ise, taşınmaz değerleme faaliyeti yürüten kurumlardaki uzmanların bizzat ziyaret edilmesi ve yapılandırılmış mülakat uygulamasının gerçekleştirilmesidir.

Yapılan araştırmalarda anket ve mülakat yöntemlerinin bazı olumlu ve olumsuz yönleri bir arada değerlendirilmiş ve daha güvenli sonuçların elde edilmesine imkân sağlamak amacıyla; taşınmaz değerleme sistemimizin etkinlik araştırılmasının mülakat yöntemiyle, değerlemede kullanılması gereken veri bileşenleriyle ilgili araştırmanın da anket yöntemiyle gerçekleştirilmesine karar verilmiştir.

\subsection{Araş̧ırma Sorularının Hazırlanması}

Mülakat formu gerek kamu gerekse özel sektördeki değerleme uzmanlarının görüşleri doğrultusunda hazırlanmıştır.

Bu mülakatlarla;

- Özel sektör değerleme uzmanlarının ve kamu kurumlarının taşınmaz değerlemesi alanında yürüttükleri faaliyetlerin,

- $\mathrm{Bu}$ faaliyetler sirasında diğer kurumlarla koordinasyon seviyelerinin,

- Uygulamada yaşadıkları sorunların,

- $\mathrm{Bu}$ sorunlarla ilgili kurumun idareci ve çalışanlarının varsa çözüm önerilerinin,

- Türkiye taşınmaz değerleme sisteminin mevcut mevzuat, kurumsal ve teknik yapısının,

- Türkiye Taşınmaz Değerleme Sistemi (TADES) olarak adlandırılan ve ülkemiz değerleme sisteminin yeniden yapılandırılmasını amaçlayan yaklaşımla ilgili düşüncelerinin,

tespiti hedeflenmiştir.

Belirlenen hedefler çerçevesinde hazırlanan mülakat formu beş bölümden oluşmaktadır (Ek-1):

- Birinci bölümde; mülakat yapılan kurum ve kişi ile ilgili bilgiler,

- İkinci bölümde; kurumun/kişinin değerlemeyle ilgili yürüttüğü faaliyetler, aynı veya benzer faaliyetleri yürüten başka kurumların bulunup bulunmadığ 1 , eğer varsa bu kurumlarla koordinasyonun seviyesi ve dayanağ

- Üçüncü bölümde; kurumun/kișinin değerlemeyle ilgili yürüttüğü faaliyetlerde karşılaştığ1 sorunlar ve varsa çözüm yaklaşımları,

- Dördüncü bölümde; ülkemizin taşınmaz değerleme sistemi mevzuatı, teknik ve kurumsal yapısıyla ilgili düşünceler, 
- Beşinci bölümde ise; mülakat yapılan kişilerin ülkemiz taşınmaz değerleme sisteminin yeniden yapılandırılmasıyla ilgili görüşleri,

sorgulanmaktadır.

Mülakat formunun hazırlanmasından sonra, ilk olarak Osmaniye'de taşınmaz değerleme faaliyeti yürüten kurumların il müdürlükleri belirlenmiştir. İlgili kurumların değerleme işlemlerinden sorumlu birimleriyle iletişime geçilerek yapılandırılmış mülakat çalışmaları gerçekleştirilmiştir. Sonrasında Adana başta olmak üzere Hatay, Mersin, Kayseri ve İzmir il ve bölge müdürlüklerinde, daha sonra da genel müdürlük ve muadili kurumlarında, idareci ve yürütücü seviyesindeki çalışanlarla mülakatlara devam edilmiştir. Resmi kurumlardaki bu araştırma çalışmaları devam ederken, bu ve diğer bazı şehirlerdeki özel sektör değerleme uzmanlarıyla da mülakatlar yapılmıştır.

Mülakat yapılacak kişilerin belirlenmesinde;

- İlgililerin, değerleme alanında, çalıştıkları kurumun en deneyimli kişileri olması,

- Taşınmazlar dünyasıyla ilgili başta harita, inşaat ve ziraat mühendisliği olmak üzere, mimarlık ve şehir/bölge planlama eğitimi almış veya en azından bu alandaki terminolojiyi olabildiğince iyi bilen uzmanlar olmas1,

- Kamu sektörü çalışanlarının mümkünse kamulaştırma bilirkişiliğgi eğitimi almış, SPK tarafindan verilen değerleme uzmanlığı lisansına sahip olması veya değer takdir komisyonlarında görev yapıyor olmas1,

- Özel sektör değerleme uzmanlarının değerleme uzmanlığı lisansına sahip olması veya uzun süredir bu alanda çalışıyor olması,

- Kamu veya özel sektör idareci konumundaki kişilerin uygulamanın içinden geliyor olması,

hususları göz önünde bulundurulmuştur.

Bu çerçevede kamu kurumları ve özel sektörde toplam 71 mülakat gerçekleştirilmiştir. Bunlardan 12'i genel müdürlük ve muadili kurumlarda yapılmıştır. İl ve bölge müdürlüklerinde gerçekleştirilen mülakatlar tamamlandıktan sonra, aynı mülakatlar ilgili kurumların merkezi otoritelerinde de gerçekleştirilmiştir. Genel müdürlük ve muadili kurumlarda gerçekleştirilen bu mülakatlarla, daha çok ilgili merkezi otoritedeki idareci veya çalışanların düşüncelerinin de alınması amaçlanmıştır. Özel sektör ve kamu kurumlarında gerçekleştirilen mülakatların tamamı, uygulama sırasında ses kaydına alınmış ve sonradan çözümlenmiştir. Görüşmeler 60-120 dakika arasında sürmüştür.

\section{BULGULAR}

Türk taşınmaz değerleme sisteminin etkinlik araştırması kapsamında gerçekleştirilen bu mülakatların sonuçları aşağıda özetlenmektedir.

\subsection{Türkiye Taşınmaz Değerleme Sistemiyle İlgili Genel Değerlendirmeler}

Ülkemizdeki taşınmaz değerleme faaliyetlerine ilişkin mevzuatta birçok madde bulunmakta, ancak bunlar birbirleriyle bağımsız olarak çalışmaktadırlar. Ayrıca bir kanunda geçen ifadeler, diğer başka bir kanunda çelişkilere neden olabilmektedir. Taşınmaz değerleme mevzuatının bu kadar çok kanununun içerisine dağınık bir şekilde bulunması, değerleme politikaları açısından düzgün işleyen bir yapının oluşturulmasına engel olmaktadır. SPK, kendi mevzuatı gereğince değerleme faaliyetlerine bir düzen getirmeye çalışsa da önemli bir ilerleme kaydedilememiştir (URL_1). Türk Hukukunda Taşınmaz Değerleme işlemlerine ilişkin sayısı yüzleri aşan düzenlemeler incelendiğinde;

- Değerleme işleminin genellikle idarece kurulan takdir komisyonu, tespit komisyonu gibi isimler altındaki komisyonlara yaptırıldı $\breve{g}$,

- $\mathrm{Bu}$ komisyonların da genellikle kurum veya kuruluş temsilcilerinden oluştuğu,

- Komisyonların oluşumunda aranan şartın öncelikle konuya taraf olunması olduğu, uzmanlık şartının ise nadiren arandığı, 
- $\mathrm{Bu}$ komisyonların çalışmalarında izleyecekleri yöntemler ile taşınmazın niteliklerine ilişkin olarak dikkate alacakları hususların, genellikle ayrıntılı şekilde düzenlenmediği,

- Değerleme çalışmalarında kullanılmak üzere herhangi bir taşınmaz karakteristikleri ve emsal satışlar veri tabanlarının oluşturulmadığ

yönünde tespitler yapılmıştır (Menteş, 2014).

Kurumsal analiz kapsamında yapilan çalışmalarda; ülkemizde taşınmaz değerleme faaliyeti yürüten kurumlar, bunların taşınmaz değerlemesi ile ilişkisi ve hangi yasalara bağlı olarak değerleme çalışmalarını sürdürdükleri araştırılmıştır. Araştırmaya göre ülkemizde, doğrudan veya dolaylı yollarla taşınmaz değerlemesi yapan birçok kurum bulunmasına karşın, bu alandaki çalışmaların organizeli bir şekilde yürütüldüğü etkin bir kurumsal yapılanma bulunmamaktadır. Buna göre ülkemizde, aynı taşınmaza ait farklı uygulamalar için farklı kurumlar tarafindan değer hesaplanmakta, hesaplanan değerler arasında da birkaç kata kadar farklar ortaya çıkmakta, bu da işlem tekrarlarına ve problemlere sebep olmaktadır. Sonuç olarak, ülkemizde kurumsallaşmış bir değerleme sistemi mevcut olmadiğ 1 , bu alandaki faaliyetlerin genellikle kurumların bünyelerinde oluşturdukları değer takdir komisyonları veya özel sektör taşınmaz değerleme şirketleri eliyle yapılmaya çalış1ldığ görülmüştür (Çete, 2008).

Teknik analiz kapsamında yapılan çalışmalarda; değerleme çalışmalarının etkin bir şekilde yürütülmesini sağlayacak standartların, veri altyapılarının ve değer haritalarının bulunmadığından, değerleme faaliyetlerinin standart bir yapida yürütülmediği görülmüştür. Bunun yanında, taşınmaz karakteristikleri ve emsal satışlar veritabanları olmadığından, değerleme uzmanları çalışmaları sırasında ihtiyaç duydukları verileri her taşınmaz için yeniden sahadan ve kurumlardan toplamak zorunda kalmakta ve bu işlemler sırasında da özellikle tapu ve kadastro müdürlükleri ile belediye gibi resmi kurumlarda çeşitli zorluklarla karşılaşmaktadırlar (Çete, 2008). Bu nedenle, sahadan veri toplama süresi uzamakta, çalışmalar zorlaşmakta ve değerleme sonuçlarının kalitesi de düşmektedir.

\subsection{Değerleme Faaliyetlerinde Karşılaşılan Sorunlar}

Türk taşınmaz değerleme sisteminin etkinlik araştırması çerçevesinde gerçekleştirilen mülakatların temel hedeflerinden biri de resmi kurumların ve özel sektör kuruluşlarının değerlemeye yönelik faaliyetlerinde karşılaştıkları sorunların belirlenmesidir. $\mathrm{Bu}$ bağlamda görüşme yapılan kişilerden, değerlemeyle ilgili çalışmaları sırasında yaşadıkları "mevzuat", "kurumsal" ve "teknik" sorunları ifade etmeleri istenmiştir. Verilen cevapların genel değerlendirmesi aşağıda alt başlıklar altında özetlenmiştir.

\subsubsection{Mevzuatla İlgili Sorunlar}

Mülakatlar sırasında ifade edilen mevzuat sorunları şu şekilde özetlenebilir:

- Ülkemizde taşınmaz değerlemesiyle ilgili başta Anayasamız olmak üzere birçok kanun, yönetmelik ve tebliğ vardır. Ancak, hiçbirinde değerleme işlemlerinin kural ve standartlarını belirten bir düzenleme yoktur. Sadece taşınmazın değerini kimlerin belirleyeceği ve hangi yöntemlerin kullanılabileceğine dair bazı maddeler vardır (Açlar ve Çağdaş, 2008; Rissi, 2010; Yomralığlu vd., 2011; Candaş, 2012; Köktürk ve Köktürk, 2015; Erdem, 2017a,b,c; Erdem, 2018a,b).

- Mevzuatlarda değerleme alanıyla ilgili birçok kuruma yetki verilmiştir. Bu durum, kurumlar arasinda yetki karmaşasına yol açmakta, tekrarlı işlemlere, uyuşumsuzluklara ve sağlıksız bir işleyişe neden olmaktadır.

- Lisanslı uzman yetersizliği nedeniyle, genel merkezleri İstanbul veya Ankara'da olan değerleme şirketleri, özellikle diğer şehirlerdeki hizmetlerini "çözüm ortakları" eliyle yerine getirmektedirler. Ancak, bu çözüm ortaklarının niteliklerini (SPK lisanslı olması gibi), belirleyen herhangi bir hukuki düzenleme bulunmamaktadır. Bu nedenle, değerleme şirketleri herhangi bir deneyimi ve yeterli eğitimi olmayan, lise veya önlisans 
mezunu kişilere rapor düzenlettirebilmektedirler.

- Değerleme faaliyetlerini ilgilendiren yasalarda çok sık değişiklikler yapıldığından, bu durum güncel mevzuatın takibini zorlaştırmaktadır.

- Taşınmaz değerine yönelik yargıya intikal etmiş davalara bakıldığında, aynı dosya için farklı tarihlerde birden fazla bilirkişi komisyonlarının oluşturulduğu, bu komisyonlardaki bilirkişilerde de herhangi bir uzmanlık belgesinin aranmadığ 1 görülmektedir. Dolayısıyla aynı taşınmaz için kurumların oluşturduğu kıymet takdir komisyonlarının verdiği değerlerle mahkemelerin oluşturduğu bilirkişi komisyonlarının verdiği değerler arasında çok büyük farklar oluşmaktadır. $\mathrm{Bu}$ durum davaların y1llarca devam etmesine ve adliyelerin iş yükünün daha da artmasina neden olmaktadir.

- Değerlemenin en önemli girdi verilerinden biri olan tapu ve kadastro kayıtları güncel değildir, yani fiili durumu yansıtmamaktadır. Örneğin taşınmaz sahibinin vefatından sonra yapılması gereken "veraset intikal" işlemleri ile taşınmaz niteliğinde meydana gelen değişikliklerde yapılması gereken "cins değişikliğgi" işlemlerinin yapılmamış olması, kamulaştırma projelerindeki değerleme faaliyetlerinde büyük sıkıntılara yol açmaktadır. Bu işlemlerle ilgili mevzuatımızda da belli bir sürede yapılmasıyla ilgili mirasçı veya malikler üzerinde bir zorlayıcılık olmaması, durumun daha karmaşı hale gelmesine neden olmaktadır.

- Ülkemizde değerleme uzmanları, piyasadaki mevcut mühendislik-mimarlık büroları veya şirketleri tarzında çalışamamaktadır.

\subsubsection{Kurumsal Sorunlar}

Mülakatlar sırasında ifade edilen kurumsal sorunlar şu şekilde özetlenebilir:

- Ülkemizde doğrudan veya dolaylı yollarla taşınmaz değerlemesi yapan birçok kurum bulunmasına karşın, bu alandaki çalışmaların organizeli bir şekilde yürütüldüğü etkin bir kurumsal yapılanma bulunmamaktadır.

- Günümüzde değerleme firmaları genellikle kalifiye eleman temininde zorlanmaktadırlar. Tecrübe kazanan elemanlar, kısa süreler içerisinde pek çok firmada çalışmakta ve çok sik şirket değiştirmektedir. Firmalar da aynı şekilde yeni mezun şahısları, düşük ücret ve k1sitlı sosyal haklarla istihdam etmektedir. Değerleme uzmanı, SPK lisansı elde edebilmesi için sağlaması gereken koşullardan biri olan 3 yıllık tecrübe süresini tamamlamak için firmalara ihtiyaç duymakta, firmalar da kâr oranını arttırmak adına, onlara ihtiyaç duyan değerleme uzmanlarını düşük ücretlerle çalıştırmaktadırlar.

- Değerleme Raporu'nun hazırlanmak için gereken verilerin çoğu belediye, Tapu/Kadastro Müdürlüğü gibi kamu kurumlarında bulunmaktadır. Ancak bu bilgilerin ilgili kurumlardan temini sırasında çok ciddi sıkıntılar yaşanmaktadır.

- Kamu kurumlarındaki taşınmaz değerlemesi faaliyetleri, kurum bünyesinde oluşturulan komisyonlar eliyle gerçekleştirilmektedir. Ancak, değer takdir komisyonlarının yapısının homojen olmaması, üyelerin herhangi bir uzmanlık belgesine veya değerleme bilimi hakkında yeterli bilgiye sahip olmamaları, çoğu zaman detaylı inceleme yapılmadan değer takdir edilmeye çalışılması gibi nedenlerden dolayı, yapılan çalışmaların geneline itiraz edilmekte ve yargiya taşınmaktadır. $\mathrm{Bu}$ nedenle mahkemelerin zaten çok yoğun olan iş yükü, bir kat daha artmaktadır.

- Mesleki deneyim ve uzmanlık gerektiren bu mesleğin birçok elemanı eksikliklerini deneme yanılma yoluyla gidermeye çalışmakta, bu da ister istemez mesleğin saygınlığına zarar vermektedir. $\mathrm{Bu}$ nedenle eğitimin kurumsallaşması gerekmektedir. Bazı üniversitelerimizin lisans bazılarının da yüksek lisans düzeyinde değerlemeye yer vermeleri yeterli değildir. 
- Gerekli belgelerle birlikte Tapu Müdürlüklerine başvuru yapılmış olmasına rağmen, sunulan belgelerin geçersiz olduğu gerekçesiyle istenilen bilgiler verilmeyebilmekte, "taşınmaz sahibinin" gelmesi talep edilebilmektedir.

- Kadastro Müdürlüklerince değerleme uzmanlarının taleplerini karşılayacak herhangi bir birim veya personel görevlendirilmesi yapılmadığı için uzmanlar kime başvuracaklarını bilememektedir.

- Bazı Kadastro Müdürlüğü personelleri uzmanların bu taleplerini karşılamayıp, onları LIHKAB bürolarına yönlendirebilmektedir.

- Tapu Müdürlüklerinin talep kabul saatlerinde farklılık olmakta, bazen duruma göre değişebilmekte, net bir uygulama bulunmamaktadir.

- Mimari Proje incelemesi için gereken ücretin kredi kartıyla ödenebilmesi uygulaması, sadece Merkez İlçe Müdürlüklerinde değil diğer tüm Müdürlüklerde de uygulanmasına ihtiyaç duyulmaktadır.

\subsubsection{Teknik Sorunlar}

Mülakatlar sirasında ifade edilen teknik sorunlar ise şu şekilde özetlenebilir:

- Ülkemizde hem kamu kurumlarında ve hem de özel sektör kuruluşlarında, toplu ve tekil taşınmaz değerlemesi çalışmalarının etkin bir şekilde gerçekleştirilmesini sağlayacak sağlıklı bir veritaban1, yöntem, sistem, değerleme standartları ve sonuç ürün değer haritaları gibi kriterler bulunmamaktadır. Toplu veya tekil taşınmaz değerlemelerinde taşınmazın değerine etki eden objektif unsurların neler olması gerektiği ve önem dereceleri konusunda bugüne kadar herhangi bir düzenleme yapılmamıştır.

- Veri temini hızlı ve çerçevesi belli bir mevzuata bağlı değildir. Örneğin, bir kişi bir kadastro müdürlüğünde veriye kolaylıkla ulaşabilirken, bir başkası aynı müdürlükte aynı veriye ulaşamamaktadır. Ocak 2013 itibariyle, Çevre ve Şehircilik
Bakanlığı'nın da kurulmasından sonra mevzuatta yapılan birtakım değişiklikler çerçevesinde, değerleme uzmanlarının tapu sicil müdürlüklerinden veri temininde bazı düzenlemeler getirilmiş olsa da, TAKBİS'ten olması gerektiği ölçüde faydalanılamamaktadır.

- Harç yatırma, tapu kaydı inceleme gibi işlemler çevrimiçi (online) sistemlere bağlanmaya çalışılıyor olsa dahi, ilgili kurumların isteksizliği, teknolojiyi yakından takip etmemeleri ve çalışanların duyarsızlığından dolayı zaman içerisinde işlemler daha da zorlaşmakta ve yavaşlamaktadır.

- Kamu kurumlarında gerçekleştirilen değerleme faaliyetlerinde görev alan komisyon üyelerinin çoğu, bu alanla ilgili herhangi bir lisans, sertifika veya eğitim almış kişiler değildir. Durum böyle olunca, aynı taşınmazın farklı komisyonlarca takdir edilen değerleri arasında çok büyük farklar gözlenmektedir.

- Değerleme çalışmalarının önemli girdi verilerinden birini oluşturan kadastral altlıklar günümüz ihtiyaçlarına cevap verememektedir. Ülkemizdeki mevcut kadastral paftaların bir kismı sayısal ortama aktarılamayacak durumdadır. İlgili alanlarda yenileme çalışmalarının yapılmas1 gerekmektedir.

- Tapu Müdürlüklerinde yapılan satış işlemlerinde satış bedeli olarak emlak beyan değerleri temel alınmakta, ancak emlak beyan değerleri piyasa değerinin yaklaşı yarısı seviyelerinde seyretmektedir. Gerçek değerinde gösterilmeyen taşınmazlar ekonomide büyük ölçekte kayı dişılık oluşturmaktadır. Emlak beyan değerlerinin 4 yılda bir güncellenmesinden dolayı şehirlerin yeni gelişim bölgelerinde güncelleme yapılamamaktadır.

- Hemen hemen her bankanın kendi değerleme rapor formatı ilgili olduğundan, uzmanlar bu şablonlara uymak zorunda kalmakta ve bu da mesleğe müdahale anlamına gelmektedir. Buna rağmen değerleme sonuçlarından 
kaynaklanacak tüm maddi hataların sorumluluğu da yine değerleme şirketlerinin üzerinde kalmaktadır.

- Bankalar değerleme raporlarını iki, üç gün gibi çok kısa bir süre içerisinde sonuçlanmasını istemektedirler. $\mathrm{Bu}$ süre çok az olup sağliklı bir rapor hazırlayabilmek için yeterli değildir. Bankaların bu tutumu hem değerleme raporlarına bağlı olarak verdikleri kredilerin risklerini arttırmakta, hem de değerleme mesleği açısından olumsuzluklara yol açmaktadır.

- Günümüzde TDUB (Türkiye Değerleme Uzmanları Birliği) tarafından belirlenen geçerli ücret tarifesinde belirtilen değerleme ücretinden daha düşük ücret ödemek isteyen işveren konumundaki bankalar mevcuttur. $\mathrm{Bu}$ durum, Gayrimenkul Değerleme Asgari Ücret Tarifesi 'ne uygun düşmemektedir.

\subsection{Değerleme Faaliyetlerinin Etkinliği İçin Öneriler}

Değerleme faaliyeti yürüten kurumlarda gerçekleştirilen mülakatlar sırasında, kurum idareci ve çalışanlarına, sözünü ettikleri sorunların çözümüne yönelik herhangi bir önerilerinin bulunup bulunmadiğı da sorulmuştur. İfade edilen öneri ve yaklaşımlar, aşağıda "mevzuat", "kurumsal" ve "teknik" öneriler alt başlıklarında sunulmaktadır.

\subsubsection{Mevzuat Önerileri}

Mülakatlar sırasında mevzuat bağlamında sunulan öneriler şu şekilde özetlenebilir:

- Ülkemizde etkin işleyen bir taşınmaz değerleme sistemini tanımlayan ve "Taşınmaz Değerleme Yasası" olarak adlandırılabilecek bir yasal düzenlemeye ihtiyaç vardır. Aksi takdirde uygulamalardaki farklılıkların ve dağınık yapının önüne geçmek mümkün olmayacaktır.

- Ülkemizdeki değerleme mevzuatının gözden geçirilerek sadeleştirilmesine, hükümlerdeki mevcut bazı çelişkilerin giderilmesine ve daha bütüncül bir yapıya kavuşturulmasına ihtiyaç vardır. $\mathrm{Bu}$ bağlamda, mevcut düzenlemeler yerine, söz konusu sıkıntıların giderilmesi noktasinda gerekli mevzuat düzenlemelerinin bir an önce yapılması ve ivedilikle Değerleme Meslek Yasası'nın çıkarılması gerekmektedir.

- Kamu kurumlarından veri temin edilirken yaşanan sıkıntıların aşılması için TDUB başta olmak üzere SPK ve BDDK, değerleme uzmanlarının inceleme ve araştırma yapma durumunda oldukları resmi kurumlar için bağlı oldukları bakanlıklar vasıtasıyla, ilgili kurumlara bilgilendirmede bulunarak, değerleme verilerinin sorunsuz ve resmi yoldan elde edilmesi için hukuki düzenlemelerin yapılmasını sağlamalıdırlar.

- Ülkemizde gayrimenkul değerlerinin kurulacak bir sistemle etkin takibi için öncelikle UDES (Uluslararası Değerleme Standartları) temelli yasal düzenlemeler yapılmas1 gerekmektedir. Yani Türkiye'de tüm değerlemelerin lisanslı değerleme uzmanlarına yaptırılmasının zemini oluşturulmalı ve oluşan bu değerlerin tek bir merkezde toplanması sağlanmalıdır.

- Veraset intikallerinin yapilmamasindan kaynaklanan sorunların giderilebilmesi ve tapu kayıtlarındaki güncel malik bilgilerine ulaşılabilmesi için, Nüfus ve Tapu Müdürlüklerinin çevrimiçi (online) iletişim içinde çalışacakları dinamik bir güncelleme sistemi geliştirilmelidir. Taşınmazların cins değişikliği işlemlerinin de talebe bağlı değil zorunlu hale getirilmesi gerekmektedir.

- Değerleme uzmanlarının bankalar dışında kamu kurum ve kuruluşlarına da bağımsız olarak değerleme hizmeti verebilmesi için yasal düzenlemeler yapılmalıdır. Değerleme mesleğini düzenleyen yasa, yönetmelik ve tebliğlerde gereken değişiklikler yapılarak, sistemin şirketler yerine doğrudan uzmanlar üzerinden yürütülmesi sağlanmalıdır.

- Değerleme uzmanlarının Kadastro Müdürlüklerinde kadastro paftalarını görme, fotoğraflarını çekme, sözlü olarak koordinatları alma ve parselin çizimini yapma gibi faaliyetlerinin ekonomik 
karş1lı̆g1 gözden geçirilmelidir. Ancak plan örneği istenmesi halinde yürürlükteki döner sermaye ücreti tahsil edilmelidir.

- SPK, BDDK ve TDUB'un, “çözüm ortağı" konusunda ivedilikle, kapsamlı ve çözüme ulaştırıcı ortak bir düzenleme yapmaları gerekmektedir.

- Gayrimenkul sektöründeki kayıt dış1lıktan dolayı emlak vergisi, değer artış kazancı, veraset intikal vergisi vb. vergilerde ciddi vergi geliri kaybı yaşanmaktadır. Yakın zamanda tapu harçlarındaki artışla, satış harc1 toplamda binde 40 oranına yükseltilmiştir. Fakat buna rağmen beklenilen gelir artışı sağlanamamıştır. Kısa vadeli pratik çözüm olarak, taşınmazların gerçek değerlerinin dikkate alındığı daha düşük oranlardaki satış vergisi oranlar1 getirilmelidir.

- Kurumlardan veri temininde yaşanan sıkıntıların aşılması için normal şartlarda, bilirkişi statüsündeki değerleme uzmanlarına, avukat vb. meslek gruplarına tanınan bazı hakların tanınması değerlendirilmelidir. $\mathrm{Bu}$ ve benzeri yapılacak düzenlemelerle, kurumlardan veri temini kolaylaştırılmalı ve verilere dijital ortamda erişim sağlanmalıdır.

- Taşınmazların değeriyle ilgili davalarda işlemlerin hızlandırılması adına ihtisas mahkemeleri kurulmalıdır. Arabuluculuk ve ombudsmanlık (kamu denetçisi) müessesesi işletilmelidir.

\subsubsection{Kurumsal Öneriler}

Mülakatlar sırasında sunulan kurumsal öneriler şu şekilde özetlenebilir:

- Ülkemizde taşınmaz değerlemesi faaliyetlerini düzenleyen, destekleyen ve denetleyen merkezi bir değerleme idaresinin tesis edilmesi gerekmektedir. Böylece özel sektör değerleme firmalarının denetimi daha etkin bir şekilde gerçekleştirilebilecektir.

- Bu alanda yeni oluşturulacak kurumun, siyasi baskılardan uzak kalmasının sağlanabilmesi için özerk bir yapılanma şeklinde düşünülmesi gerekir. Böylece, değerleme konusunda bir ihtilaf çıktığ 1 takdirde kişiler mağdur olmadan veya mahkemeye gitmeden sorunlarını çözme imkânına sahip olabileceklerdir.

- Değerleme kuruluşları bankaların faaliyetlerine herhangi bir müdahalede edemiyorsa, bankaların da değerleme şirketlerine bu konuda herhangi bir müdahalesi olmamalıdır. Bankalar bu alandaki düşüncelerini BDDK, SPK veya değerleme faaliyetlerinden sorumlu olacak yeni bir lider kuruma bildirmelidirler.

- Değerleme çalışmalarının, kurumların bünyesinde oluşturulan komisyonlar yerine, bu alanda sadece değerleme lisansına sahip değerleme uzmanları tarafından yürütülmesi gerekmektedir. Değerleme alanında kullanılmakta olan kamulaştırma bilirkişiliği sertifikası uygulamas1 da kaldırılmalıdır. $\mathrm{Bu}$ ve benzeri köklü değişiklikleri yapabilmek için öncelikle bu alanda güçlü bir kurumsal yapılanma oluşturulmalıdır.

- Şu an ülkemizde sadece bir üniversitede değerleme alanında lisans derecesinde eğitim verilmektedir. Değerleme mesleğinin sosyal ve ekonomik yönden ülkemiz adına taşıdığı önem dikkate alındığında, SPK, BDDK, TDUB ve ilgili diğer kurum ve kuruluşlar, üniversitelerde bu bölümün açılmasını veya taşınmazlarla ilgili bölümlerde değerlemeyle ilgili derslerin verilmesi için çalışmalar yapmalıdırlar.

- Sektör içerisinde değerleme uzman1değerleme firması, banka ve resmi kurumlar arasındaki döngüyü iyileştirmek ve geliştirmek gerekmektedir.

- Kadastro ve Tapu Müdürlüklerince değerleme uzmanlarına hizmet verecek personel görevlendirmesi asil ve yedek olarak yapılmalıdır. Değerleme raporlarının hazırlanma sürecinin kısaltılabilmesi için Kadastro ve Tapu Müdürlükleri değerleme uzmanlarına tam gün hizmet vermelidirler.

- TKGM bünyesinde yürütülmekte olan TKMP'nin değerleme dişındaki bileşenlerinde ciddi çalışmalar yapılmış ve karşıllı̆g 1 alınmıştır. Taşınmaz değerleme bileşeninde ise proje ile amaçlanan ve ülkemize en uygun modelin 
ortaya koyulması, bu doğrultuda politika geliştirilmesi hedefi ve şehir bazlı pilot uygulamalar henüz gerçekleştirilememiştir. Başlatılan bu çalışmaların daha ileri noktalara taşınması gerekmektedir.

- Kamulaştırmayi gerçekleştiren kurum tarafından değerleme uzmanlığ sahip kişilere yaptırılan kıymet takdirleri, mahkemeler tarafindan dikkate alınmamaktadır. Oysa alternatif raporların da dikkate alınması gerekir. Mahkemelerce oluşturulan değer takdir komisyonlarının üyeleri de uzmanlık belgesine sahip kişilerden oluşmalıdır.

- TDUB'un, bir meslek odası işlevine sahip olmas1, yöneticilerinin daha yetkili bir hale getirilmesi, görev tanımının genişletilmesi ve Birlikçe hazırlanacak taslakların mesleğe yön vermesi gerekmektedir.

- Yeni oluşturulacak yapıda, değerleme şirketlerindeki lisanslı değerleme uzmanı sayısı ikiye düşürülmelidir. Böylece, şirketin sermaye miktarı azaltılarak veya bu şirketlerde bir derecelendirmeye gidilerek, İstanbul veya Ankara merkezli değerleme firmalarından ziyade, ülke geneline homojen dağılmış özel değerleme firmalarının kurulmasına imkân sağlanmalıdır.

- Kamu hariç diğer özel kişi ve kuruluşların değerleme ihtiyaçları sadece lisanslı özel değerleme kuruluşları tarafindan karşılanmalıdır.

\subsubsection{Teknik Öneriler}

Mülakatlar sırasında sunulan teknik öneriler şu şekilde özetlenebilir:

- Taşınmaz değerlemesi alanında gelişmiş sistemlere sahip ülkelerde olduğu gibi, ülkemizde de değerleme çalışmaları sırasında ihtiyaç duyulan verilere erişilebilmesi ve çalışmaların sağlıklı bir altyapı çerçevesinde gerçekleştirilebilmesi için, taşınmaz karakteristikleri ve taşınmaz piyasasındaki gerçek alım-satım değerleriyle ilgili bilgileri içeren veritabanları kurulmalıdır. Taşınmaza ait bilgilerin ortak bir veritabanından elde edilebilmesi, değerleme uzmanlarının ihtiyaç duydukları verilere daha kısa sürede ve kolayca ulaşabilmesini sağlayacaktır.

- Vergilendirme amaçlı değerlemelerde toplu değerleme yöntemleri uygulanmal1, bunun mesleki standartlar çerçevesindeki uygulamaları için ülkemize uyan standartlar getirilmelidir.

- TKGM tarafindan kullanılan TAKBİS sisteminde taşınmazların sınıflandırılması daha sağlıklı bir yapıya kavuşturulup, çeşitlerine göre satışı yapılan taşınmazlar ve değerleri, il ve ilçe bazında güncel olarak resmi sitesinden ilan edilmelidir.

- Belediyelerce verilen yap1 ruhsatları ve yap1 kullanma izin belgelerinin sayıları belli bir sinıflandırma yöntemi kullanılarak ilan edilmelidir. Belediyelerin kaçak yapılaşmayı önlediği varsayılarak taşınmaz piyasası için sağlıklı bir arz talep eğrisi oluşturulmalıdır.

- SPK tarafindan, UDES ve Türkiye'deki mevcut taşınmaz mevzuatı dikkate alınarak, bankalar ve diğer kuruluşlar için her taşınmaz türüne göre ayrı ayrı olmak üzere ortak bir değerleme rapor formatı geliştirmelidir. Böylece, hem ileride oluşturulmak istenen değerleme veritabanı için önemli bir başlangıç olacak ve hem de tekrarlı değerleme işlemlerinin önüne geçilebilecektir.

- Değerlemesi yapılacak taşınmazların niteliklerine göre, raporlama süreleri bu alandaki dünya standartlarına uygun olarak belirlenmelidir.

- Kat Mülkiyeti Kanunu'na göre bağımsız bölümlerin yüzölçümlerinin mimari projede gösterilmesi zorunlu olduğundan, mevzuat değişikliğine gerek duyulmaksızın, belediyelerce onaylı mimari projedeki listede bağımsız bölümlerin yüzölçümlerinin gösterilmesi ve TAKBIS siteminde bu konuda bir düzenleme yapılması gerekir.

- Taşınmaz değerleme sektörünün bakanlık, üniversiteler vb. kurumlarla ortak çalışarak homojen bir yapının oluşturulması sağlanmalıdır. Bunun için 
sadece değerleme sektörü değil, türevi olan ve satışlara aracılık eden gayrimenkul danışmanlıklarının da hukuki altyapısı oluşturularak, satışlarda piyasa rayiç değerinin tapuya yazılması sağlanmalıdır. $\mathrm{Bu}$ sayede oluşan sektör büyüklüğü daha iyi analiz edilerek yatırımların daha doğru yapılmasının yolu açılacaktır.

- Değerleme uzmanlarına verilere erişim konusunda kanunlar çerçevesinde bazı ayrıcalıklar tanınmalı, gerekiyorsa belli ve uygun harçlar karşılığında, birtakım verilere erişimlerini kolaylaştırmak ve memur/görevli şahıslarla iletişimlerini minimuma indirip çevrimiçi olarak verilere ulaşmaları sağlanabilir. Özellikle verilerin elektronik ortamda oluşturulması ve saklanması işlemleri hızlandıracaktır. Örneğin kadastro paftaları, tapu kayıtları, imar paftaları gibi veriler çevrimiçi veritabanlarında çeşitli yazılımlar sayesinde, şifreli olarak değerleme uzmanlarına sunulabilir. Bunun için gerekli altyapı düzenlemeleri yapılabilir. Resmi kurumlarda uygulanması gereken, çevrimiçi sistemlere geçiş süreci uzun olabileceğinden, tüm kurumlarda tek bir karar uygulanması daha kisa vadeli bir çözüm olarak düşünülebilir. Böylece herkes her kurumdan eşit hizmet alabilir.

- SPK lisanslama sinavlarındaki modüller gereğinden fazla detayı ve meslek alanından uzak konuları içermektedir. Meslekte önemli olan sahada yapılan çalışmalardır. Bir kişi modüllere çalışarak, değerleme uzmanlığı hakkında en ufak fikre sahip olmasa dahi, sınavlarda başarılı olabilir. Bu, o kişinin, değerleme uzmanı olma yetisine sahip olduğu anlamına gelmez. SPK lisanslama sınavlarında kişilerin sahada yaşadıkları problemlere yönelik sorular olması ve kişinin tecrübe süresinin ölçülebildiği bir sinav sistemi getirilmesi gerekir.

- Değerleme hizmeti veren kurum ile veriyi üreten kurumların birbirleri ile aktif bir bağının olmaması gerekir. Ancak, ülkemizde aynı kurumlar verileri üretmekte, değerlemede kullanmakta ve yine aynı kurumlar değerleme sonuçlarını kontrol etmekte ve onaylamaktadır.
- Değerleme kullanılan yazılım ve personelin milli olması gerekir. Ayrıca, sistemi devam ettirebilmek için de yetişmiş eleman şarttır. Yoksa en iyi sistem de kurulmuş olsa devamını getirecek teknik eleman olmadan sistem devam ettirilemez.

- TDUB, statüsünde belirtilen görevi gereği, Gayrimenkul Değerleme Asgari Ücret Tarifesi'ne uymayan bankalar hakkında SPK ve BDDK'ya başvurarak, yasal işlemlerin yapılmasını sağlamalı ve bunu da kamuoyu ile paylaşmalıdır.

\section{SONUCCLAR ve TARTISSMA}

Ülkemiz taşınmaz değerleme sisteminin etkinliğinin arttırılabilmesi için, öncelikle mevcut durum analizinin ve bu alanda faaliyet yürüten kamu ve özel sektör değerleme uzmanlarının geliştirilecek sistemden beklentilerinin sağlıklı bir şekilde belirlenmesi gerekmektedir. Eksiklik ve sorunların tam anlamıyla ortaya koyulması, başarılı bir şekilde çözüme ulaşmayı sağlayacaktır. Ayrıca, uygulamanın içinde yer alan değerleme uzmanlarının tecrübe ve önerileri de geliştirilecek çözümün uygulanabilirliğini arttırma bakımından önem arz etmektedir.

Türk taşınmaz değerleme sisteminin etkinlik araştırması çerçevesinde, taşınmaz değerleme sistemimizin mevcut yapısinın aksayan yönleriyle ilgili yasal, kurumsal ve teknik açıdan yeniden yapılandırmaya ihtiyaç duyulduğu görülmektedir. Yukarıdaki ifadelerden de anlaşılacağı üzere, değerleme faaliyeti yürüten kamu ve özel sektör kurumlarının idareci ve çalışanlarına göre, mevcut taşınmaz değerleme sistemimiz etkin işleyen bir yapıya sahip değildir. Bunun başlıca nedeni, gerek değerleme alanında ihtiyaç duyulan verilerde (doğruluk, güncellik vb. açısından) gerekse bu verileri sunan kamu kurumlarında yaşanan sorunlardır. Nitekim ifade edilen problemlerin daha çok tapu, kadastro, belediye gibi kamu kuruluşlarında yoğunlaşması da bunun önemli bir göstergesidir. $\mathrm{Bu}$ sebeple, ülkemizde sürdürülebilir bir taşınmaz değerleme sisteminin gerçekleştirilebilmesi için, sağlıklı bir mevzuat altyapısına sahip, doğru ve güncel bir değerleme veritabanı sisteminin 
oluşturulmasına ve etkin bir değerleme kurumunun yapılandırılmasına ihtiyaç vardır.

Ülkemiz değerleme sisteminin etkinliğinin geliştirilebilmesi için öncelikle;

- Değerleme çalışmalarında ihtiyaç duyulan verilerin,

- Veritabanı organizasyonunun,

- $\mathrm{Bu}$ verilerin hangi kurum/kuruluşlarca ve ne şekilde oluşturulup/sağlanıp sürdürüleceğinin,

- Veri paylaşımının ne şekilde gerçekleştirileceğinin,

- Sistemin ürünlerinin ve değerleme çalışmalarının hangi kurum ve kuruluşların organizasyonu ve yönetiminde gerçekleştirileceğinin,

kapsamlı bir şekilde belirlenmesi gerekmektedir.

\section{BÍLGILENDİRME}

Bu makale; Yük. Müh. Nuri ERDEM'in 2016 yılında Erciyes Üniversitesi Fen Bilimleri Enstitüsü Harita Mühendisliği Anabilim Dalında tamamlanan "Türkiye Için Bir Taşınmaz Değerleme Sistemi Yaklaşımı" isimli doktora tez çalışmasından üretilmiştir.

\section{TEŞEKKÜR}

Çok yoğun çalışmaları arasında zamanlarını ayırarak bu çalışmanın gerçekleştirilmesine katkı sağlayan, çok kıymetli görüş ve tecrübelerini benimle paylaşan, kamu ve özel sektör taşınmaz değerleme uzmanlarına teşekkür ederim.

\section{KAYNAKÇA}

Açlar, A., Çağdaş, V., (2008). Taşınmaz (Gayrimenkul) Değerlemesi, TMMOB Harita ve Kadastro Mühendisleri Odas1, ISBN 975-395-551-0, Ankara, $500 \mathrm{~s}$.

Candaş, E., (2012). Taşınmaz Değerlemesi İçin Mevzuat Altyapısının Modellenmesi, İstanbul Teknik Üniversitesi, Fen Bilimleri Enstitüsü, Yüksek Lisans Tezi, İstanbul, $131 \mathrm{~s}$.

Çete, M., (2008). Türkiye İçin Bir Arazi İdare Sistemi Yaklaşımı, Karadeniz Teknik
Üniversitesi, Fen Bilimleri Enstitüsü, Doktora Tezi, Trabzon, $243 \mathrm{~s}$.

Çete, M., Yomralıoğlu, T., (2009). Türkiye için bir arazi idare sistemi yaklaşımı, HKMO, Jeodezi, Jeoinformasyon ve Arazi Yönetimi Dergisi, Say1:100, ISSN1300/3534.

Erdem, N., (2017a). Türkiye İçin Bir Taşınmaz Değerleme Sistemi Yaklaşımı, Geomatik Dergisi, 2(3); 18-36, ISSN: 2564-6761.

Erdem, N., (2017b). Türkiye İçin Bir Taşınmaz Değerleme Sistemi Yaklaşımında Temel Veri Yönetimi, Geomatik Dergisi, 2(2);6685, ISSN: 2564-6761.

Erdem, N., (2017c). Türkiye İçin Bir Taşınmaz Değerleme Sistemi Yaklaşımının Geliştirilmesi, Uluslararası Hakemli Mühendislik ve Fen Bilimleri Dergisi, Doi: 10.17366/uhmfd.2017.3.1, Issn Online: 2148-47-83 Online: 2149-2484.

Erdem, N., (2018a). Türkiye'de Taşınmaz Değerleme Alanında Yapılan Lisansüstü Tezlerinin İçerik Analizi, APJES 6-1 (2018) 112-126, Doi: 10.21541/apjes.332681

Erdem, N., (2018b). Türkiye Taşınmaz Değerleme Sisteminin Yeniden Yapılandırılmasına Yönelik Bilimsel Çalışma Ve Öneriler Üzerine Bir Değerlendirme, Ömer Halisdemir Üniversitesi Mühendislik Bilimleri Dergisi, Cilt 7, Sayı 1, 159-170, ISSN: 2564-6605, doi: 10.28948/ngumuh.386408

EU, (2004). European Union Land Policy Guidelines, Guidelines for Support to Land Policy Design and Land Policy Reform Processes in Developing Countries, EU Task Force on Land Tenure.

HKMO, (2012). Sempozyum Bildiriler Kitab1, Arazi Yönetiminde Taşınmaz Değerleme ve Kadastro Sempozyumu, ATO Uluslararas1 Kongre ve Sergi Saray1, HKMO\&TKGM, 22-23 Mayis, Ankara, 240 s.

Köktürk, E., Köktürk, E., (2015). Taşınmaz Değerlemesi, Taşınmaz Hukuku - İmar Hukuku - Değerleme Yöntemleri, Seçkin Yayınc1lık, 2. Baskı, Ankara, ISBN 978975-02-312, $1304 \mathrm{~s}$.

Menteş, M., (2014). ÇŞB'de Taşınmaz Değerleme Uygulamaları, TKGM Tapu ve Kadastro Modernizasyon Projesi Taşınmaz Değerleme Orta Dönem Toplantısi, Dedeman Oteli, Şubat, İstanbul.

Rissi, S., B., (2010). Entwicklung Türkischer Immobilienbewertungsverfahren, basierend auf den Erfahrungen der Deutschen Wertermittlungsmethoden, Technische Universität München, Institut für Geodäsie, GIS und Landmanagement Lehrstuhl für Bodenordnung und. 
URL_1: http://www.ekspermedia.com/tasinmazdegerleme-kanunun-gerekliligi/, (E. T.: Eylül 2015)

Yomralıŏlu, T., Nişancı, R., Çete, M., Candaş, E., (2011). Dünya'da ve Türkiye'de taşınmaz değerlemesi, Türkiye'de Sürdürülebilir Arazi Yönetimi Çalıştayı, 26-27 Mayıs, Okan Üniversitesi, İstanbul.

EK-1

A. MÜLAKAT YAPILAN KIŞ̇ं İLE ILGILI BILGILER

\begin{tabular}{|l|l|l|l|}
\hline \multicolumn{3}{|c|}{ Mülakat Yapılan Kişi Ile Ilgili Bilgiler } \\
\hline Adı Soyadı & \multicolumn{3}{|c|}{} \\
\hline Kurumu & Mesleği & \\
\hline Görevi & Deneyim Süresi & \\
\hline Telefonu & E-postasi & \\
\hline
\end{tabular}

\section{B. MEVCUT DURUM TESPITI (KURUM BAZLI)}

Soru 1. Kurumunuzda taşınmaz değerlemesine hangi faaliyetlerde ihtiyaç duyulmaktadır?

Soru 2. Değerleme çalışmaları hangi mevzuata göre yürütülmektedir?

Soru 3. Bu çalışmalarda değerlemeleri kim/kimler gerçekleştirmektedir?

Soru 4. Değerleme çalışmalarını yürüten kişiler hangi meslek dallarındandır?

\begin{tabular}{|lll}
$\square$ Harita Mühendisi & $\square$ İnşaat Mühendisi & Ziraat Mühendisi \\
\hline İşletmeci & $\square$ İktisatçı & $\square$ Mimar \\
$\square$ Şehir Plancı & $\square$ Tekniker-teknisyen & $\square$ Diğer (varsa lütfen aşağıda belirtiniz)
\end{tabular}

Soru 5. Değerleme çalışmalarını gerçekleştirmek için bu kişilerde herhangi bir yeterlilik belgesi aranmakta mıdır? (Cevabınız "Hayır" ise Soru 7'ye geçiniz)

Soru 6. Bu hangi belgelerdir ve kim tarafindan verilmektedir?

Soru 7. Kurumunuzda değerleme çalışmalarını gerçekleştirecek kişiler nasıl seçilmektedir?

Soru 8. Değerlemelerde hangi verilerden yararlanılmaktadır?

Soru 9. Bu veriler hangi kurumlardan temin edilmektedir?

\section{YAŞANAN SORUNLAR VE ÖNERILER (KURUM BAZLI)}

Soru 10. Kurumunuzca yürütülen taşınmaz değerlemesi faaliyetlerinde (varsa) karşılaşılan hukuki, kurumsal ve teknik sorunlar ve bu sorunların çözümüne yönelik önerileriniz nelerdir?

a) Hukuki Sorunlar ve Öneriler: (Mevzuat yetersizliği, mevzuatla ilgili sorunlar vb.)

b) Kurumsal Sorunlar ve Öneriler: (Değerlemeleri gerçekleştiren yap ile ilgili sorunlar vb.)

c) Teknik Sorunlar ve Öneriler: (Ihtiyaç duyulan verilere erişimde yaşanan sorunlar, değerleme sistemiyle ilgili sorunlar $v$ b.)

\section{SPK VE TDUB ILLE ILGILİ DEĞERLENDİRMELER}

Soru 11. Sermaye Piyasası Kurulu (SPK)'nın değerleme alanında yürüttüğü faaliyetler ile ilgili değerlendirmeleriniz nelerdir?

Soru 12. SPK tarafından verilmekte olan gayrimenkul ve konut değerleme uzmanlığı lisansları ile ilgili değerlendirmeleriniz nelerdir?

Soru 13. Türkiye Değerleme Uzmanları Birliği (TDUB)'nin mevcut yapısı ve işleyiş̧i ile ilgili değerlendirmeleriniz nelerdir? 


\section{E. YENIDEN YAPILANMA IHTIYYCI ARAŞTIRMASI}

Soru 14. Sizce ülkemizdeki mevcut değerlemeyle ilgili yasalarında bir belirsizlik ve dağınıklık söz konusu mudur? (Cevabını "Hayır" ise "Soru 16" geçiniz)
Evet
$\square$ Kismen
Hayır

Soru 15. Sizce, ülkemizdeki taşınmaz değerlemesi düzenlemelerinin "Taşınmaz Değerleme Kanunu" gibi ayrı bir yasa altında yeniden düzenlenmesine ihtiyaç var mıdır? Neden?

$\square$ Evet $\square$ Hayır

Gerekçesi:

Soru 16. Ülkemizdeki taşınmaz değerlemesi kurumsal yapısının yeniden yapılandırılmasına ihtiyaç var mıdır? (İlk seçeneği seçtiyseniz, Soru 18'e geçiniz)

$\square$ Mevcut yap1 yeterlidir

$\square$ Mevcut kurumların iyileştirilmesi gerekmektedir

$\square$ Kurumsal yapının genel anlamda yeniden yapılandırılması gerekmektedir

Soru 17. Sizce nasil bir kurumsal yapı olmalıdır?

Soru 18. Önerdiğiniz yapının ne tür riskleri olabilir?

Soru 19. Ülkemizde değerlemeden sorumlu lider bir kurum oluşturulmasına ve bu kurumun ülke genelindeki taşınmaz değerlerini adaletli vergilendirme ve farklı amaçlarla belirlemesi yaklaşımına nasıl bakarsınız? (Üçüncü seçeneği seçtiyseniz, Soru 21'ye geçiniz)

$\square$ Olumlu

Soru 20. Sizce bu lider kurum hangi kurum olmalı?

$\square$ Yeni yapılandırılacak bir kurum (Lütfen düşündüğünüz bir kurum adı belirtiniz)

$\square$ Tapu ve Kadastro Genel Müdürlüğü

$\square$ Belediyeler

$\square$ Maliye Bakanlığ

$\square$ İller Bankası A.Ş.

$\square$ Diğer (Lütfen kurum adı belirtiniz)

Soru 21. Bu tür bir kurumun varlığını olumlu veya olumsuz bulma nedenleriniz nelerdir?

Soru 22. Değerleme sistemimiz yeniden yapılandırılacak olursa, yeni yapıda özel sektör değerlemecileri ile değerleme kurumu arasında nasıl bir görev paylaşımı olmalıdır?

Soru 23. Sizce aşağıdaki veri/bilgilerden hangisi veya hangileri yeni yapı tarafından üretilmeli ve güncellenmelidir?

$\square$ Taşınmaz özellikleri veri tabanı

$\square$ Emsal satış verileri

Taşınmaz değer haritaları

Diğer (Lütfen belirtiniz) 